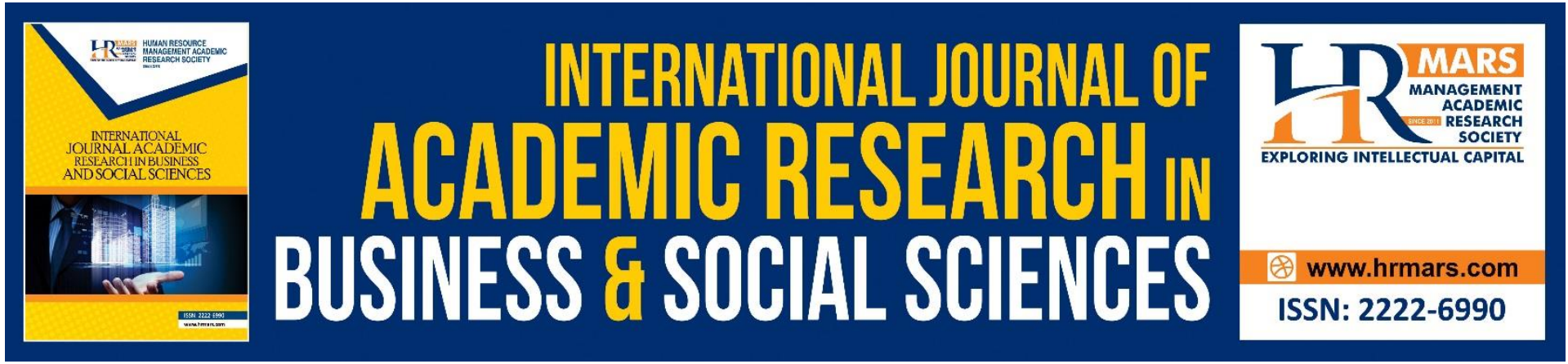

\title{
Impact of Covid-19 on Malaysian Environment in 2020
}

\section{Haliza Abdul Rahman, Nur Afrina Qistina Ahmad Halmi}

To Link this Article: http://dx.doi.org/10.6007/IJARBSS/v11-i8/10785

DOI:10.6007/IJARBSS/v11-i8/10785

Received: 10 June 2021, Revised: 16 July 2021, Accepted: 01 August 2021

Published Online: 17 August 2021

In-Text Citation: (Rahman \& Halmi, 2021)

To Cite this Article: Rahman, H. A., \& Halmi, N. A. Q. A. (2021). Impact of Covid-19 on Malaysian Environment in 2020. International Journal of Academic Research in Business and Social Sciences, 11(8), 889-903.

Copyright: (C) 2021 The Author(s)

Published by Human Resource Management Academic Research Society (www.hrmars.com)

This article is published under the Creative Commons Attribution (CC BY 4.0) license. Anyone may reproduce, distribute, translate and create derivative works of this article (for both commercial and non-commercial purposes), subject to full attribution to the original publication and authors. The full terms of this license may be seen at: http://creativecommons.org/licences/by/4.0/legalcode

Vol. 11, No. 8, 2021, Pg. 889 - 903

http://hrmars.com/index.php/pages/detail/IJARBSS

JOURNAL HOMEPAGE

Full Terms \& Conditions of access and use can be found at http://hrmars.com/index.php/pages/detail/publication-ethics 


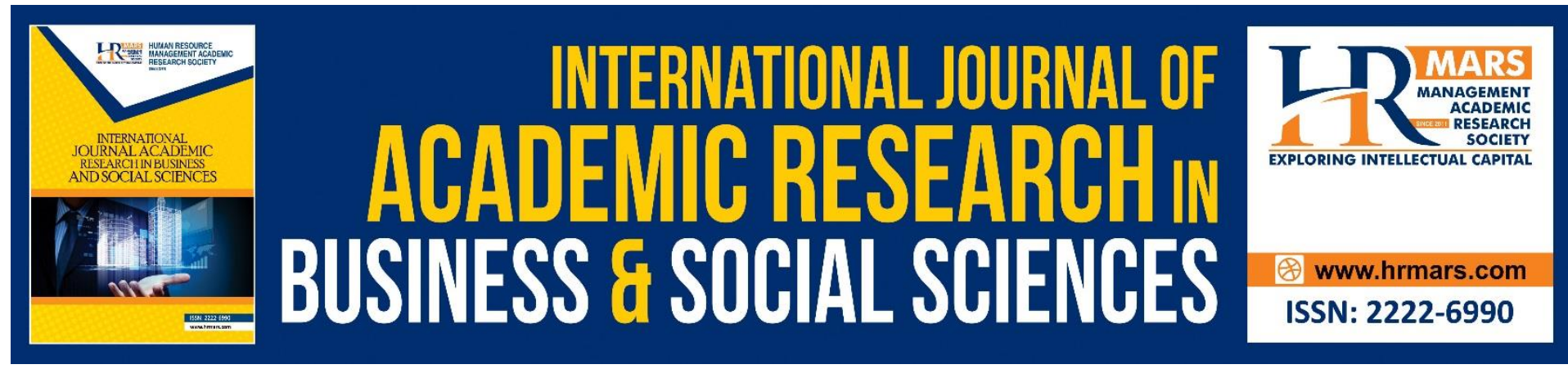

\title{
Impact of Covid-19 on Malaysian Environment in 2020
}

\author{
Haliza Abdul Rahman \\ Institute for Social Science Studies, Universiti Putra Malaysia, 43400 Serdang, Selangor \\ Department of Environmental and Occupational Health, Faculty of Medicine and Health \\ Sciences, Universiti Putra Malaysia, 43400 Serdang, Selangor. \\ Email:dr.haliza@upm.edu.my
}

\section{Nur Afrina Qistina Ahmad Halmi}

Institute for Social Science Studies, Universiti Putra Malaysia, 43400 Serdang, Selangor

Department of Environmental and Occupational Health, Faculty of Medicine and Health

Sciences, Universiti Putra Malaysia, 43400 Serdang, Selangor.

\begin{abstract}
The World Health Organisation (WHO) declared the Corona Virus has fast-spreading known as a pandemic. The geographical, climatic, political and social factors are example can be influenced by Covid-19 epidemic. This article has discussed the impact of Covid-19 on the environment in Malaysia, especially towards air and river quality, and waste disposal. Thus, extensive literature was identified from various, and related documents such as journals and reports to study on the impact of Covid-19 towards an environment in Malaysia in 2020. The aim of this article is to discuss the effects of Covid-19 on the Malaysian environment, especially towards air and water quality and ways to deal with it. Selected works of literature on the impact of Covid-19 towards an environment in Malaysia in 2020 was identified. The first case in Malaysia was detected on January 24 2020, then fast-spreading until May 30 2020, in total, 7,762 reported cases in Malaysia. Due to the cases, the 'COVID Waste" is generated on excessive of masks, gloves, and hand sanitiser bottles. The environmental damage has returned with a vengeance because of the spreading of disposable face masks has increased, which can cause pollution to the environment. All Malaysians must be careful in disposing of used face masks to protect fellow Malaysians and the environment. Meanwhile, the authorities should raise awareness of the proper way to remove used face masks. It is suggested to make posters and advertisements to remind the public about the need to remove used face masks safely.
\end{abstract}

Keywords: Environmental, Covid-19, Impact, Nature, Environmental Health

\section{Introduction}

Corona Virus is a disease similar to pneumonia cases. This virus also well names as Covid-19. The virus has appeared in December 2019 and began to emerge in Wuhan City, China. Many researchers have thought that the source of Covid-19 is starting to occur in the Huanan 
Seafood market in Wuhan. Thus, the researcher has identified that the virus has transmitted from animal to human, which can widely spread from human to human (Atalan, 2020). The World Health Organisation (WHO) declared that the Covid-19 has fast-spreading known as a pandemic. Then, in March 2020, WHO has second announced that the Covid-19 is a "universal pandemic" and called for an aggressive worldwide response.

Many people around the world hastened to go home and started to worried about the virus (Megahed \& Ghoneim, 2020). Statistics about Covid-19 on April 16, 2020, have a cumulative number of confirmed cases that have exceeded 2 million people and caused around 130,000 deaths. A total of 213 countries and regions around the world have been affected by this pandemic (Wang \& Su, 2020). The disease has rapidly spread around the world and has eventually affected in every continent except Antarctica (Chakraborty \& Maity, 2020). Consequently, Covid-19 has alarming implications for social functioning and emotional, which has been transformed by human physical health. The Corona Virus proved that a catastrophe does not fight with a known challenger. This challenger can simply be unseen with devastating consequences (Wang \& Su, 2020).

This universal pandemic has also significantly influenced human professional and personal lives, which has a direct bearing upon the fundamental of architecture theory and practices, urban planning, and property sectors. According to that, the digital world is friable about cyberattacks. The cybersecurity should protect our built environment from being a teachable moment by applying lessons due to this pandemic (Megahed \& Ghoneim, 2020). Most of the countries have many attempts to fight the spread of the Covid-19 by conduct extensive screening tests and develop public policies of social distancing. The priority of doing this test is revolved people's health around the world. For this reason, the indirect impact of Covid-19 has been analysed (Zambrano-Monserrate, Ruano, \& Sanchez-Alcalde, 2020).

According to Coronavirus disease (COVID-19) in Malaysia, 2020, the first case in Malaysia was detected on January 24 2020, then fast-spreading until May 30 2020, in total, 7,762 reported cases in Malaysia. Malaysia COVID 19 cases soared after March 5 Cases increased sharply by $80 \%$ to 428 on March 15, which compared to 238 on the previous day. Therefore the subsequently cases are up to 2,908 on April 1 . The cases were reported from a religious gathering, attended by 16,000 people, including 14,500 Malaysians. About half of the total cases in the country are reported from the group. The government is trying to track down more than 2,000 Rohingya men who attended the event and have not yet appeared for testing as they are considered illegal immigrants. Then, the virus keeps spreading in Malaysia when one of the Malaysia citizens arrived from Wuhan to Johor. The first human-to-human transmission of coronavirus in Malaysia was detected on March 12, causing concerns of the pandemic spread.

Consequently, to manage this pandemic, professionals from every sector, such as architecture, design agencies, and urban planning, have switched they envision on the postpandemic era. Professionals need to search for practical design ideas, planning, and theories and trends to prove the required protection from the virus attacks. It is continuously to add more layers of protection in the defence system for the built environment (Megahed \& Ghoneim, 2020). This article is evaluating the potential transmission of Covid-19 towards the environment and how to overcome this problem. This article is conducted an in-depth discussion of environmental challenges and changes in environmental pollution such as air pollution during the period form this pandemic. The primary control of the Covid-19 will be discussed further in the next sections. This article discusses the effects of Covid-19 on the 
environment, especially towards air and water quality and ways to deal with it and aimed to show the positive and indirect Covid-19 impact towards the environment in Malaysia.

\section{Method}

In this article, selected works of literature on the impact of Covid-19 towards an environment in Malaysia in 2020 was identified from December 2019 till May 2020. However, this article was only focussing on air pollution and river quality and waste disposal. Extensive literature was identified from various and related documents such as journals, reports, proceedings and newspapers. The issues will be discussed further in the discussion section.

\section{Literature}

\section{Covid-19 And Global Environment}

Statistics report on April 16 2020, shows that the cumulative number of confirmed cases of Covid-19 has increased to 1.99 million. The region in the United States of America has contributed to the highest number of cases followed by Europe (Bi et al., 2020). These two provinces have more than a hundred thousand deaths. Apart from that, every big and small cities and village on the affected countries such as China, Italy, Taiwan, Germany, Korea, Australia, India, and many more are under Restricted Movement Order or LockDown for an extended period between weeks to months. All central administrations and local worldwide have decided to ban on the free movement of the citizen to avoid Covid-19 transmission. The mass gathering events on religious, cultural, social sport, political, and scientific such as Hajj, Concert, Club, Olympic, etc. are cancelled. Thus, the vehicles are barely found on the roads, which results in zero-emission of green-house gases toward the environment.

Also, the demand for power in industries such as fossils fuels and any conventional energy source has declined rapidly. Therefore, ecosystems are slowly being recovered (Chakraborty \& Maity, 2020). Within a few months, people from many big cities are experiencing to see a clear river and sky from polluted for the first time in their lives. The tourist spots such as forests, sea breaches, hill areas have shrinkage the pollution level. Indirectly, the Covid-19 pandemic has affected every creature in this world. The impact of the healthcare system has been devastating. The medical team and front liners are facing unprecedented situations and challenges. The front liners need to struggle to cope up with this outbreak.

Preventive measures have been taken by a dermatologist to control virus transmission. The preventive measures, like hand hygiene practice and practice social distancing between patients and doctors, is being prioritised. Non-urgent visits of the patients in the hospital were discouraged. Besides, the conference or events on Dermatological across the world has been postponed cancelled due to gathering and hard to practice social distance if the event is still on (Bhat et al., 2020). This pandemic has shown its consequences on human civilisation, and the world leads to destruction (Chakraborty \& Maity, 2020).

In Malaysia, the threat of COVID-19 became increasingly apparent when neighbouring Singapore reported the first COVID-19 case was imported from Wuhan, China, on January 23, 2020. This case was the first positive case in the republic. From this first case, eight close contacts were identified in Johor, Malaysia (Abdullah et al., 2020). In less than 48 hours from the first case reported in Singapore, Malaysia published a positive COVID-19 case on January 25 2020. These positive cases ware imported from Wuhan, China (Abdullah, 2020). A total of eight positive cases were reported within six days, starting from the first case. All these cases are cases imported from China. Malaysia's first positive test for COVID-19 was reported on 
February 3 2020; this person has a history of travelling to a neighbouring country for a business meeting, which is also attended by representatives from China (Reinhardt et al., 2015).

\section{Potential Transmission of Covid-19 Towards Environment}

It is imperative to understand the potential transmission of Covid-19 towards the environment. Since human is basically will spend most of their daily life inside the built environment. The individuals must beware of the potential transmission dynamic of infection. Covid-19 can be transmitted by air via direct or in-direct contact. The small particles can be flying directly and landed on the surface due to the nature of airflow patterns or another source of turbulence in the indoor environment. Therefore, it is essential to implement healthy housing, which is highly suggested by WHO. The unclean home environment has a high density could lead to unhygienic conditions, which will spread several infectious diseases. Thus, anti-virus built environment will prevent from increasing the risk of volatile infections and droplets-transmitted infections (Megahed \& Ghoneim, 2020).

According to Munawer (2018), in assess, whether the Covid-19 outbreak harms the environment, the use of concentration of Nitrogen dioxide (NO2) in the air as an environmental indicator. The high level of $\mathrm{NO} 2$ in the atmosphere will cause nutrient pollution, which causes smog. The accumulation of this pollutant of air and water will cause severe environmental pollution. Besides, the NO2 is harmful to human health. The breathing of air, which containing a high concentration of NO2, will stimulate the body's respiratory failure. The toxicity of nitrogen gas will erode the lung tissue. Besides, the exposure of a high concentration of NO2 can cause respiratory problems such as wheezing, difficulty to breath, and coughing (Wang \& Su, 2020). Moreover, the National Aeronautics and Space Administration (NASA) and European Space Agency (ESA) have tracked from satellites, that the concentration of NO2 in the air across in China has decreased significantly. Due to this Covid-19 epidemic, human activities that lead to pollution have limited, which causes the cases to infection are declining (Wang \& Su, 2020).

\section{Impacts and Challenges}

Geographical, climatic, political, and social factors are an example which can influence the Covid-19 epidemic. Based on the potential transmission of Covid-19 around the world and required measures, several conferences, competitions such as "Olympic 2020", concerts, and leagues have been cancelled or postponed. The coronavirus cases also have motivated the authorities to control access to the most public spaces and large shopping area. This pandemic could change the way they revised the plan in the future and require further analysis of the Coronavirus (Megahed \& Ghoneim, 2020).

The challenges, issues, and conflicts have been highlighted by the authorities to ensure long-term sustainability, reliability, and energy security (Vaka et al., 2020). In Korea, researchers found that, from the previous experience, the risk of spreading influenza was increased with low temperature and high relative humidity. The cold and dry weather is beneficial for the survival and spread of influenzas diseases. There was experimental and epidemiologic evidence that indicates the variations of humidity account in the transmission of pandemic influenzas such as H1N1 and SARS. The most outbreaks of pandemic influenza during spring and summer (Shaman, Goldstein, \& Lipsitch, 2011). Moreover, many researchers stated that the SARS epidemic slowly inactive with the hot weather coming and 
ended in July 2003. Some studies are suggested that climate change might spread numerous infectious diseases (Park, 2020).

Therefore, the countries currently suffering the most Covid-19 pandemic, which are mostly located in the regions with low temperatures. This is one of the features of the Covid19 epidemic. Thus, the meteorological factors such as humidity, and ambient temperature plays an important role to avoid the disease from spreading (Liu et al., 2020). The coronavirus generates adverse indirect effects on the environment. For example, in the USA, some cities were suspended from the recycling program. The authorities in the USA have been concerned about the risk of spreading coronavirus in recycling centres. Thus, in the European nations has significantly affected. For example, in Italy, the authorities have been restricted and prohibited from the infected residents form sorting their waste. There is food waste generated by households has been increased. Apart from that, human tends to purchased online food. The increasing of solid waste or food waste has to have an impact on the environment (Zambrano-Monserrate et al., 2020). Their government took the precaution to control the Covid-19 from spreading by control on the waste management (ZambranoMonserrate et al., 2020).

\section{How to Prevent Virus Infection in The Environment}

The ongoing health crisis will inevitably develop our built environment to increase the security layer that helps prevent the spread of infections and diseases. In this context, there are many areas of research needed on Covid-19. If Covid-19 has no specific vaccine, the physical distancing and Movement Restrict Order among the residents need to immediate and preventive measures to be taken. By choosing the best anti-virus strategy depends on many factors, such as the abilities and capabilities of each community and environment. Global pandemics have highlighted the limitations of how we manage our built environment on how we should plan, build, and run our built environment. WHO has introduced these measures, which are practised at the institutional and individual levels, to become a universal mainstream strategy. Other factors and wearing protective clothing influence the spread of infection. However, the WHO continues to change and update all distances mentioned based on the latest information and research conducted by professionals (Megahed \& Ghoneim, 2020). This changes experienced by society to reduce the spread of infection. It can be seen widely from health care, government, society, industry, environment, energy, and also its impact in the future. The effect of MCO on the environment due to Covid-19 has been addressed in many studies. It has been observed that the climate has begun to be renewed as all types of industries, vehicle movements, and social activities of people continue to be at low levels for a long time. In particular, the positive effect of lockdown restrictions on air and water quality has been observed (Atalan, 2020).

To prevent and control the spread of COVID-19 nationwide, district governments take measures such as external bans, closed management, and travel restrictions. From a spatial perspective, the reduction of environmental pollution initially appears in areas with severe outbreaks because they first apply strict limits. After that, more and more provinces are implementing quarantine measures and implementing traffic control. Furthermore, various strategies have been followed by multiple countries and global agencies to combat COVID19. A large number of states follow full closures, part of home and mass quarantines, prohibited/prohibited international and domestic travel, banned public gatherings, mass inspections, increased emergency financial support, fines imposed, curfews, and emergencies (Lal et al., 2020). The social distancing policies adopted by the governments following the 
appearance of the pandemic (Zambrano-Monserrate et al., 2020) Also, the essential step to reduce the spread of coronavirus or to prevent infection is to follow hygiene rules. The most important thing is to wash your hands.

For this reason, the range of this virus is slower in people who have the habit of washing their hands and observing the rules of general hygiene. Such extreme measures to control infections have the potential to result in decreased aerosols and atmospheric pollutants due to anthropogenic-based emission disorders (Lal et al., 2020). Based on previous knowledge of MERS and SARS infections, WHO wants to reduce the risk of COVID-19 transmission, in general, has recommended some precautions such as avoiding close contact with people suffering from acute respiratory illness, washing hands with soap \& plain water or hand sanitiser especially after direct contact with a sick person or his or her environment, maintaining a cough ethic, and avoiding unprotected contact with livestock or wild animals, etc. from various countries postponed all kinds of religious, cultural, social, scientific, sports, and political mass gathering events in different parts of the world (Chakraborty \& Maity, 2020)

Table 1 shows the guidelines for government, public and health working. All parties should play an essential role in due to eradicate the Corona Virus.

\begin{tabular}{|c|c|c|c|}
\hline No. & $\begin{array}{l}\text { Guidelines } \\
\text { Government }\end{array}$ & Guidelines for Public & $\begin{array}{l}\text { Guidelines for Health } \\
\text { Workers }\end{array}$ \\
\hline 1. & $\begin{array}{l}\text { Provide educational } \\
\text { awareness } \\
\text { communicate with public } \\
\text { activities through risk } \\
\text { communication } \\
\text { communication } \\
\text { involvement }\end{array}$ & $\begin{array}{l}\text { Follow government and } \\
\text { coordination to fight COVID- } \\
\text { 19. Show support, kindness, } \\
\text { and compassion to those } \\
\text { affected and avoid social } \\
\text { stigma. }\end{array}$ & $\begin{array}{l}\text { Healthcare workers should } \\
\text { follow established safety } \\
\text { protocols and procedures to } \\
\text { diagnose, triage and treat the } \\
\text { patients. }\end{array}$ \\
\hline 2. & $\begin{array}{l}\text { Find active cases by } \\
\text { testing, tracking the travel } \\
\text { history of the infected } \\
\text { person, quarantining } \\
\text { contacts, and isolating the } \\
\text { infected person. Adjust } \\
\text { the existing surveillance } \\
\text { system to monitor the } \\
\text { spread of infection. }\end{array}$ & $\begin{array}{l}\text { Get enough information about } \\
\text { COVID-19. More watching, } \\
\text { listening, and reading the } \\
\text { news about the situation can } \\
\text { make a person feel anxious or } \\
\text { depressed. Also, focus on facts } \\
\text { and avoid misinformation or } \\
\text { rumours. Get information only } \\
\text { from trusted sources (WHO or } \\
\text { local health body platform). }\end{array}$ & $\begin{array}{l}\text { Make sure the patient } \\
\text { admitted should cover their } \\
\text { nose and mouth when } \\
\text { sneezing or coughing. Also, } \\
\text { patients with suspected } \\
\text { COVID-19 should be given a } \\
\text { mask while they wait. }\end{array}$ \\
\hline 3. & $\begin{array}{l}\text { Test all the individuals who } \\
\text { meet the definition of a } \\
\text { suspected case }\end{array}$ & $\begin{array}{l}\text { Protect yourself by adopting } \\
\text { proper preventive measures } \\
\text { and also help others who are } \\
\text { in need. Find a way to enhance } \\
\text { the positivity among the } \\
\text { family and society. }\end{array}$ & $\begin{array}{l}\text { Follow hand hygiene after } \\
\text { contact with respiratory } \\
\text { secretions }\end{array}$ \\
\hline 4. & $\begin{array}{l}\text { Enforcement of health } \\
\text { screening. The function of } \\
\text { screening is to increase } \\
\text { further the detection of } \\
\text { fever among tourists and }\end{array}$ & $\begin{array}{l}\text { Respect the health workers, } \\
\text { doctors, and others who } \\
\text { support the struggle of this } \\
\text { epidemic that also includes } \\
\text { you. }\end{array}$ & $\begin{array}{l}\text { Taking care of your mental } \\
\text { health is just as important as } \\
\text { your physical health. Try to } \\
\text { stay in touch with your loved } \\
\text { ones through digital }\end{array}$ \\
\hline
\end{tabular}




\begin{tabular}{|l|l|l|l|}
\hline & $\begin{array}{l}\text { locals returning from } \\
\text { abroad if the identified } \\
\text { patients need to isolate in } \\
\text { a particular quarantine } \\
\text { area for COVID-19. }\end{array}$ & $\begin{array}{l}\text { communication and also with } \\
\text { your colleagues. Take the } \\
\text { necessary rest. After all, this is } \\
\text { a marathon and not a sprint. }\end{array}$ \\
\hline 5. & $\begin{array}{l}\text { Increase the number of } \\
\text { hospitals that could treat } \\
\text { Covid-19 cases. }\end{array}$ & $\begin{array}{l}\text { Keep washing hands regularly, } \\
\text { wear a face hovering over the } \\
\text { nose and mouth in enclosed } \\
\text { spaces. Stay at least a meter } \\
\text { away from the people in } \\
\text { public, but not in with the } \\
\text { household. }\end{array}$ & $\begin{array}{l}\text { Mandatory } \\
\text { requirements to have a safe } \\
\text { practice. More specific } \\
\text { guidance by using Personal } \\
\text { Protective Equipment (PPE) to } \\
\text { treat the patients. }\end{array}$ \\
\hline
\end{tabular}

Source: (Madurai Elavarasan \& Pugazhendhi, 2020)

Table 1 shows the guidelines for government, public and health working

\section{Results}

\section{Covid-19 Towards Air in Malaysia}

In China, its government has announced restrictions on movement orders. The checkpoints of movement orders are starting from building entrances to any outdoor activities. This preventive measure includes traffic restrictions for non-emergency vehicles and the closure of non-essential public places. The residents in each city only receive living needs from neighbourhood and community committees due to the existence of quarantine policies. The train station is also closed as a precaution for the people from entering the city. As a result, air quality nationwide has improved significantly. (Wang \& Su, 2020). The proven letter needs to show as live or work there for entering the city. As the city's transportation and industrial activities declined, China's energy consumption declined significantly during the quarantine period. This is because China is a major consumer of coal, and coal resources dominate the energy consumption structure (Wang \& Su, 2020). The extreme measures like these to control viruses could potentially result in decreased aerosols and atmospheric pollution due to anthropogenic-based emissions disorders (Lal et al., 2020). Given the environmental aspects, quarantine has left people living at home, resulting in less air pollution due to less industrial activity, and the movement of vehicles. In India, about 21 cities out of the 30 most polluted cities in the world and has reported declining air pollution as well as residents experiencing cleaner air during the Movement Restrict Order (Elavarasan \& Pugazhendhi, 2020). Nearly half of the world experienced partial or complete closure due to the COVID-19 epidemic, which resulted in the closure of industrial and motor vehicles and related reductions in the concentration of atmospheric pollution (Lal et al., 2020).

Further, environmental problems include air pollution, water pollution, climate change, depletion of the ozone layer, global warming, depletion of groundwater levels, changes in biodiversity \& ecosystems, arsenic pollution, and more (Coutts, Beringer, \& Tapper, 2010). From the desire to push nature by their wants and desires, human beings began to destroy the environment in many ways as an inevitable consequence; environmental pollution has become a significant issue nowadays (Chakraborty \& Maity, 2020). Thus, COVID19 significantly reduces the concentration of $\mathrm{NO} 2$ in the atmosphere. This reduction initially occurred around Wuhan and eventually spread throughout the country. From a spatial perspective, the reduction of environmental pollution initially appears in areas with severe outbreaks because they first apply strict restrictions. After that, more and more provinces are 
implementing quarantine measures and implementing traffic control. As a result, air quality nationwide has improved significantly. This phenomenon seems to indicate a close relationship between the economy and environmental pollution. Reduced economic activity and traffic restrictions directly affect China's energy consumption changes and effectively reduce ecological pollution (Wang $\& \mathrm{Su}, 2020$ ).

\section{Covid-19 Towards River in Malaysia}

Due to urbanization and modernization, river water pollution is a severe problem in Malaysia and has an adverse impact on the sustainability of water resources (Afroz \& Rahman, 2017). According to the Malaysian Environmental Quality Report 2016, out of 477 monitored rivers, only $47 \%$ of the rivers were classified as clean and the rest were slightly polluted (43\%) and polluted (10\%) (The Department of Environment, 2016). Subsequent monitoring in 2017 showed that the percentage of clean rivers was declining. A total of 219 (46\%) of the 477 supervised rivers were categorized as clean, 207 (43\%) were slightly polluted and 51 (11\%) were polluted (The Department of Environment, 2017). The major causes of pollution to the 52 rivers are related to anthropogenic activities. Specifically, the sources of contamination are caused by industrial areas, sewages, workshops, residential areas, animal husbandry activities, example pig farms, agricultural activities, landfills, plantation activities, market, food court and hawker stalls (The Malaysian Administrative Modernisation and Management Planning Unit, 2009).

These anthropogenic influences cause elevated concentrations of heavy metals, mercury, coliforms and nutrient loads (Khatri and Tyagi, 2015). Another report released by the Department of Environment (DoE) (2018) was almost identical. The main pollution loads were from 5 main sources, namely manufacturing industries, agricultural-based industries, sewage treatment plant, piggery and wet market. Specifically, a total of 653 tonnes/day of Biochemical Oxygen Demand pollution load, 835 tonnes/day of Suspended Solids Load pollution load and 205.3 tonnes/day of Ammoniacal Nitrogen Load were released in 2018 (Chai, 2020).

The effects of pollution on the ecosystem of the river is extremely alarming. There are several other incidents related to river water pollutions in 2018 and 2019 that affect the sustainability of cities, especially in relation to the environment, economic and social. These examples include rivers in Selangor, Johor, Penang and Perak. As example, On March 7, 2019, river pollution occurred in Sg. Kim-Kim, Pasir Gudang, Johor due to illegal chemical waste dumping. Due to this illegal waste has released toxic fumes, 6000 people were affected. In fact, 2775 residents have been hospitalized, as well as 111 schools and 92 kindergartens and nurseries have been closed (Chia, 2019). Several toxic gases, such as acrylonitrile, xylene, methane and toluene were emitted following the interaction of the chemicals concerned with water and air. Sg. Kim Kim crisis was unique because it started with water pollution, then followed by air pollution (Chia, 2019).

Data in 2016 and 2017 has shown that most of Malaysia's river water quality was in Water Quality Index Class II and Class III. However, the implementation of the Movement Control Order (MCO) has restricted business activities, human movements as well as anthropogenic activities. The sudden decline in human activities has directly impacted the river water quality (Chai, 2020). Several observations conducted by reporters of local newspapers, reports released by the Department of Environment (DoE) and Ministry of Environment and Water have shown positive changes in water river quality. 
As example, the impact of Covid-19 towards river in Malaysia makes of of the river which Mahang river in peril. Water in the Mahang River, which flows through several villages in Kampung Ulu Mahang, Kulim, Kedah used to flow clear as crystal, but those days are over due to sand mining and logging activities (TheStarTV.com, 2020). Moreover, Sg. Kim Kim, a river infamous for having chemical waste pollution, has recently begun to recover. It is clearer and recovering after it was cleaned. The implementation of the Movement Control Order (MCO) has contributed to the recovery of river water. The factories and industries around have stopped operations during Movement Control Order (MCO) (Noh, 2020). Most of rivers in Klang Valley were recovering during the Movement Control Order (MCO) (Dorall, 2020). Areas in Sentul and Kepong have seen marked improvements in their stretches of Sg. Gombak. Parts of Sg. Klang, from Melawati to Keramat, have also seen similar improvement in water quality. A total of 43\% less waste is removed from Sg. Klang. From March 15, 2020 to April 15, 2020, 580 metric tonnes of rubbish were collected under the Selangor Maritime Gateway (SMG) project compared to an average of 900 to 1,200 metric tonnes per month over the last six months. Sg. Klang recorded Class III Water Quality Index (WQI) readings almost $90 \%$ of the time, compared to 2019 until March, 2020, whereby although the overall WQI stood at Class III as well, it was only for about 46 percent of the time (Malay Mail, 2020). In fact, a report released by the Department of Environment (DoE) on April 18, 2020 shows that there was an increase in the river water quality index in Sg. Linggi in Negeri Sembilan, Sg. Muar and Sg. Johor in Johor, Sg. Pahang and Sg. Kuantan in Pahang, Sg. Besut in Terengganu, Sg. Kelantan in Kelantan, and Sg. Btg Sadong in Sarawak.

\section{Covid-19 Towards Waste Disposal in Malaysia}

The 'COVID Waste" is also posing with excessive of masks, gloves, and hand sanitiser bottles in dumpsites and more found in the sea is categories as clinical waste.. The environmentalists see an increase in plastic pollution from the surgical mask. The Ocean Asia Environmental group had revealed that it had seen the increase in the number of face masks while researching on the Hong Kong coast (DW, 2020). The environment and waste management expert Dr. Theng Lee Chong are said, the disposal face masks which are ended up in the streets, dumpsite or landfill are "a big threat to the environment." When people are throwing away a pile of mask-like rubbish, throwing it away without separation or even recycling, it poses a risk to the environment and public health.

The United Nations Environment Program (UNEP) has advised that the disposal of public waste or the incineration of medical household waste can cause severe pollution that poses a threat to human health and the environment. For example, severe SARS cases in China in the past. The Chinese government has introduced a centralised collection system for medical waste with appropriate separation. UNEP also advises that waste related to Covid-19 be segregated at the household level, with garbage containers closed and stored safely from scavengers. Also, Garbage Operators, it is recommended, should also ensure that they wash their hands thoroughly after sealing the bag.

In Malaysia, Federal Territory Director of Solid Waste Management and Public Cleansing (SWCorp) Mohd Zahir Shari said, the community should throw away their used face masks in a clean way instead of throwing them in the bin with other rubbish. Millions of Malaysians have been using face masks since the Covid-19 pandemic began, with supplies on the market drying up. A three-layer surgical mask is only used once a day for each person. This causes thousands of face masks to be removed every day, causing more mask waste in Malaysia. Mohd Zahir said the community should be more careful about how to remove their 
used face masks (Wang et al., 2020). Apart from that, it is also worrying that many people ignore the advice from the government when these face masks are found scattered everywhere, such as in drains, sidewalks, escalators, and by the roadside. Used face masks will pose a risk to public health. this is because they may be infected with covid virus. used face masks should not be thrown at random like regular rubbish (New Straits Times, 2020).

In the Klang Valley, half of the community has practised a lot in separating garbage so that it becomes a recyclable and non-recyclable bin. Most residential homes and condominiums have various containers with standard labels for plastic, paper, glass, tin, household waste, and more. Therefore, the Malaysian government may need to add particular bins for face masks. It is essential because there is no very simple vaccine for pandemics on the market. The World Health Organization itself has reversed previous decisions and continues to encourage people to wear masks every time they go out. Lately, there has been a surge in the use of recyclable covers, whether of rubber or cloth. But awareness is still low, with many opting to use three-tiered variations just because they are now readily available. Effective removal of face masks, as well as related Covid-19 waste, will be a headache for countries around the world. While the world continues to fight the epidemic, the challenge for all of us is also to protect the environment and not to let go of the profits made by Mother Nature during the closure (Aluga, 2020).

\section{Conclusion}

Coronavirus outbreak of 2019 has dramatically affected people around the world and radically alters routine human functions. As a species on this earth, we must use our talented intelligence to discover the coronavirus of this novel. Using technology, proper governance, health services, coordinated public behaviour can help a lot in reducing risk. Technological support in dealing with this situation is irreplaceable. So, in this section, we will summarise the key aspects of each section and analyse the current challenges associated with it - the indirect positive and negative effects of Covid-19 on the environment.

The first part presents the technological changes that society and the environment have undergone from various aspects (Elavarasan \& Pugazhendhi, 2020). The idea of an independent organisation is the answer to protecting the environment and ecological systems - fewer cars, more cycling, and walking. One of the valuable lessons we will learn is to have a network of cycling and walking routes. Walking, as the primary means of transportation and physical activity, is proven to be environmentally friendly and beneficial for the physical and mental health of the population (Wu et al., 2020).

In combating infection and maintaining social distance, cities should offer safer roads and smaller pedestrian walkways and micro-mobility than relying solely on mass public transportation. Although considered the right environmental solution to reduce pollution, public transport is not suitable during disease outbreaks because it can contribute to the spread of disease among consumers (Megahed \& Ghoneim, 2020).

The Ministry of Environmental in Malaysia has state that the air and river pollutants have decreased, indicating that the air and river quality is gradually increasing. This is because of the disruption in human and industrial activities during MCO (Kanniah et al., 2020). However, there is a pollution of "Covid Waste" that will increase. Not many people consider face masks as harmful waste, and they are not paying much attention after their use. Face masks used by the health and patient ranks are treated as medical waste (and disposed of following strict rules). However, the same cannot be said about face masks worn by the 
general public. The usual practice when you get home is to quickly throw away the face mask and throw it in the trash.

In short, all Malaysians must be careful in disposing of used face masks to protect fellow Malaysians and the environment. Meanwhile, the authorities should raise awareness of the proper way to remove used face masks. For example, fold and then wrap the face mask in a plastic bag before throwing it away from the air. There should be posters and advertisements to remind the public about the need to remove used face masks safely. Laws can be enacted to impose heavy penalties on those who do not remove the mask used properly. It is also suggested that special face shields should be placed in public places, such as train stations, supermarkets, shopping malls, schools and government departments that are frequently visited by the public. All offices, businesses, apartments and condominiums should also have this special bin. Therefore, the government has to convinced most of Malaysians to wear face mask in public, this is because there is no to Covid-19 pandemic vision, but this has helped us predict the shape of post-pandemic architecture and urbanism.

\section{References}

Abdullah, J. M., Wan Ismail, W. F. N., Mohamad, I., Ab Razak, A., Harun, A., Musa, K. I., \& Lee, Y. Y. (2020). A critical appraisal of COVID-19 in Malaysia and beyond. Malaysian Journal of Medical Sciences, 27 (2), 1-9. https://doi.org/10.21315/mjms2020.27.2.1

Abdullah, N. H. (2020). Kenyataan Akhbar KPK 9 Mac 2020 - Situasi Semasa Jangkitan Penyakit Coronavirus 2019 (COVID-19) di Malaysia. Retrieved from:

https://kpkesihatan.com/2020/03/09/kenyataan-akhbar-kpk-9-mac-2020-situasisemasa- jangkitan-penyakit-coronavirus-2019-covid-19-di-malaysia/

Afroz, R., Rahman, A. (2017). Health impact of river water pollution in Malaysia. International Journal of Advance and Applied Science, 4(5), 78-85

Aluga, M. A. (2020). Coronavirus Disease 2019 (COVID-19) in Kenya: Preparedness, response and transmissibility. Journal of Microbiology, Immunology and Infection, 53 (5), 671673. https://doi.org/10.1016/j.jmii.2020.04.011

Atalan, A. (2020). Is the lockdown important to prevent the COVID-9 pandemic? Effects on psychology, environment and economy-perspective. Annals of Medicine and Surgery, 56, 38- 42. https://doi.org/10.1016/j.amsu.2020.06.010

Bhat, Y., Aslam, A., Hassan, I., \& Dogra, S. (2020). Impact of COVID-19 pandemic on dermatologists and dermatology practice. Indian Dermatology Online Journal, 11 (3), 328-332. https://doi.org/doi: 10.4103/idoj.IDOJ_180_20.

Bi, Q., Wu, Y., Mei, S., Ye, C., Zou, X., Zhang, Z., Feng, T. (2020). Epidemiology and transmission of COVID-19 in 391 cases and 1286 of their close contacts in Shenzhen, China: a retrospective cohort study. The Lancet Infectious Diseases, 20, 911-919. https://doi.org/10.1016/S1473-3099(20)30287-5

Chakraborty, I., \& Maity, P. (2020). COVID-19 outbreak: Migration, effects on society, global environment and prevention. Science of the Total Environment, 728, 138882. https://doi.org/10.1016/j.scitotenv.2020.138882

Chai L. G. (2020). The river water quality before and during the Movement Control Order.(MCO) in Malaysia. Case Studies in Chemical and Environmental Engineering, 2, 100027. https://doi.org/10.1016/j.cscee.2020.100027

Chia, R. G., Business Insider. (2019). Johor Gas Poisoning Victims Now at 2,775, but PM Mahathir Says the Situation Is 'under Control'. Retrieved from: 
https://www.businessinsider.my/johor-gas-poisoning-victims-now-at-2775-but-pmmahathir-says-the-situation-is-under-control

Coutts, A., Beringer, J., \& Tapper, N. (2010). Changing Urban climate and CO2 emissions: Implications for the development of policies for sustainable cities. Urban Policy and Research, 28 (1), 27-47. https://doi.org/10.1080/08111140903437716

Dorall, A. (2020). Rivers in the Klang Valley Are Recovering without Human Interference during MCO. Retrieved from: https://www.therakyatpost.com/2020/04/11/rivers-in-theklang-valley-are-recovering-without-human-interference-during-mco

Apostolou, N. (2020). Coronavirus plastic waste polluting the environment. Retrieved from https://www.dw.com/en/coronavirus-plastic-waste-polluting-the- environment/a53216807

Kanniah, K. D., Kamarul Zaman, N. A. F., Kaskaoutis, D. G., \& Latif, M. T. (2020). COVID-19's impact on the atmospheric environment in the Southeast Asia region. Science of the Total Environment. 736, 139658. https://doi.org/10.1016/j.scitotenv.2020.139658

Lal, P., Kumar, A., Kumar, S., Kumari, S., Saikia, P., Dayanandan, A., Khan, M. L. (2020). The dark cloud with a silver lining: Assessing the impact of the SARS COVID-19 pandemic on the global environment. Science of the Total Environment, 732, 139297. https://doi.org/10.1016/j.scitotenv . 2020.139297

Lim, J. (2020). Hazard in the rubbish bin. Retrieved from https://www.thestar.com.my/metro/metro- news/2020/03/25/hazard-in-rubbish-bin Liu, J., Zhou, J., Yao, J., Zhang, X., Li, L., Xu, X., He, X., Wang, B., Fu, S., Niu, T., Yan, J., Shi, Y., Ren, X., Niu, J., Zhu, W., Li, S., Luo, B., \& Zhang, K. (2020). Impact of meteorological factors on the COVID-19 transmission: A multi-city study in China. Science of the Total Environment, 726, 138513. https://doi.org/10.1016/j.scitotenv.2020.138513

Madurai Elavarasan, R., \& Pugazhendhi, R. (2020). Restructured society and environment: A review on potential technological strategies to control the COVID-19 pandemic. Science of the Total Environment, 725, 138858. https://doi.org/10.1016/j.scitotenv.2020.138858

Malay Mail. (2020). MCO Has Led to a Much Cleaner Klang River. Retrieved from https://www.malaymail.com/news/malaysia/2020/04/20/mco-has-led-to-a-muchcleaner- klang-river/1858635

Martin, B. (2020). 'COVID waste' littering the planet. Retrieved from https://www.thestar.com.my/opinion/columnists/on-your-side/2020/07/10/covidwaste- littering-the-planet

Megahed, N. A., \& Ghoneim, E. M. (2020). Antivirus-built environment: Lessons learned from Covid-19 pandemic. Sustainable Cities and Society, 61, 102350. https://doi.org/10.1016/j.scs.2020.102350

Munawer, M. E. (2018). Human health and environmental impacts of coal combustion and post- combustion wastes. Journal of Sustainable Mining, 17 (2), 87-96. https://doi.org/10.1016/j.jsm.2017.12.007

Noh, M. F. (2020). Sg. Kim Kim Is Recovering during the MCO [Sungai Kim Kim Semakin Pulih Ketika PKP]. Retrieved from: Berita Harian.https://www.bharian.com.my/berita/nasional/2020/04/681836/ sungaikim-kim-semakin-pulih-ketika-pkp?_ga=2.25319741.1297871281.1589479458-484745 269.1589479445

Park, S. E. (2020). Epidemiology, virology, and clinical features of severe acute respiratory syndrome-coronavirus-2 (SARS-COV-2; Coronavirus Disease-19). Korean Journal of 
Pediatrics, 63 (4), 119-124. https://doi.org/10.3345/cep.2020.00493

Public health risk in discarded face masks I New Straits Times. (2020). Retrieved from https://www.nst.com.my/opinion/letters/2020/05/594780/public-health-riskdiscarded-face- masks

Reinhardt, I. C., Jorge, C. O., Ring, D. T., Raj, A., Dwivedi, G., Sharma, A., ... Scavone, V. (2015). Some Considerations Regarding the International Real Estate Market - Present and Future Predictions. Procedia Computer Science, 91(Itqm), 106193. https://doi.org/10.1016/j.finmar. 2014.11.002

Shah, A., Safri, S., Thevadas, R., Noordin, N., Rahman, A., Sekawi, Z., Ideris, A., \& Hameed Sultan, M. T. (2020). COVID-19 outbreak in Malaysia: Actions taken by the Malaysian government. International Journal Of Infectious Diseases, 97, 108-116. https://doi.org.10.1016/j.ijid.2020.05.093

Shaman, J., Goldstein, E., \& Lipsitch, M. (2011). Absolute humidity and pandemic versus epidemic influenza. American Journal of Epidemiology, 173 (2), 127-135, https://doi.org/10.1093/aje/kwq347

The Sun Daily Public apathy, illegal factories main causes of river pollution. (2019). Retrieved from: https://www.thesundaily.my/local/public-apathy-illegal-factories-main-causesof-river- pollutio $n-C X 707271$

The Department of Environment (DoE) Laporan Kualiti Alam Sekeliling Malaysia 2016 [Malaysian environmental quality report 2016] (2016). Retrieved from: https://www.doe.gov.my/portalv1/wp-content/uploads/2018/09/iv-EQR2016.pdf

The Malaysian Administrative Modernisation and Management Planning Unit (2009). Sungai Yang Tercemar Mengikut Negeri Dan Punca Punca Pencemarannya Pada Tahun 2009 [Rivers Polluted by State and Their Sources of Pollution in 2009]. Retrieved from: http://www.data.gov.my/data /ms_MY/dataset/sungai-yang-tercemarmengikut-negeri-dan- punca-punca-pencemarannya- pada-tahun2009/resource/9f97906c-124e-4164-8ee9- 862c6b462eda

The Star TV com. (2020). Mahang River In Peril |Thestartv.Com. [online] Retrieved from: https://www.thestartv.com/v/mahang-river-in-peril

Vaka, M., Walvekar, R., Rasheed, A. K., \& Khalid, M. (2020). A review on Malaysia's solar energy pathway towards carbon-neutral Malaysia beyond Covid '19 pandemic. Journal of Cleaner Production, 273, 122834.

https://doi.org/10.1016/j.jclepro.2020.122834

Wang, C., Zhao, L., Lim, M. K., Chen, W. Q., \& Sutherland, J. W. (2020). Structure of the global plastic waste trade network and the impact of China's import Ban. Resources, Conservation and Recycling, 153, 104591.

https://doi.org/10.1016/j.resconrec.2019.104591

Wang, Q., \& Su, M. (2020). A preliminary assessment of the impact of COVID-19 on environment - A case study of China. Science of the Total Environment. 728, 138915. https://doi.org/10.1016/j.scitotenv .2020.138915

World Health Organization (WHO) (2020). Coronavirus Disease (COVID-19) In Malaysia. [online] Retrieved from: https://www.who.int/malaysia/emergencies/coronavirusdisease-(covid-19)-in-malaysia>

Wu, C., Chen, X., Cai, Y., Xia, J., Zhou, X., Xu, S., Huang, H., Zhang, L., Zhou, X., Du, C., Zhang, Y., Song, J., Wang, S., Chao, Y., Yang, Z., Xu, J., Zhou, X., Chen, D., Xiong, W., Xu. L., Zhou, F., Jiang, J., Bai, C., Zheng, J., \& Song, Y. (2020). Risk Factors Associated with Acute Respiratory Distress Syndrome and Death in Patients with Coronavirus Disease 2019 
Pneumonia in Wuhan, China. JAMA Internal Medicine, 180 (7), 934-943. https://doi.org/10.1001/jamainternmed . 2020.0994

Zambrano-Monserrate, M. A., Ruano, M. A., \& Sanchez-Alcalde, L. (2020). Indirect effects of COVID-19 on the environment. Science of the Total Environment, 728, 138813. https://doi.org/10.1016/j.scitotenv.2020.138813 